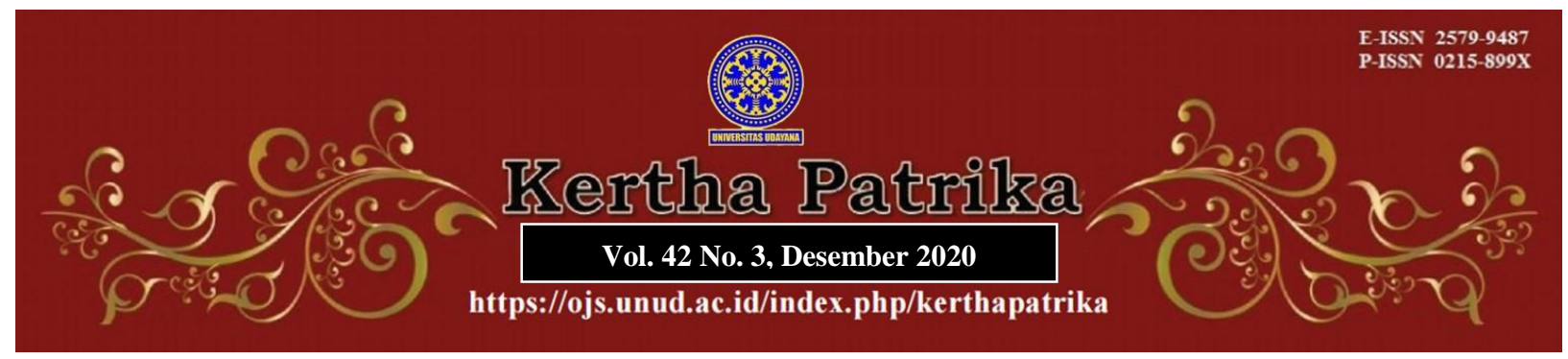

\title{
Hak Kurator untuk Mengajukan Praperadilan terhadap Boedel Kepailitan yang Diletakkan Sita Pidana
}

\section{Lukman Ilman Nurhakim¹, Efa Laela Fakhriah ${ }^{2}$}

${ }^{1}$ Magister Ilmu Hukum Universitas Padjadjaran, E-mail: lukman15002@unpad.ac.id

2 Fakultas Hukum Universitas Padjadjaran, E-mail: efalaela69@yahoo.co.id

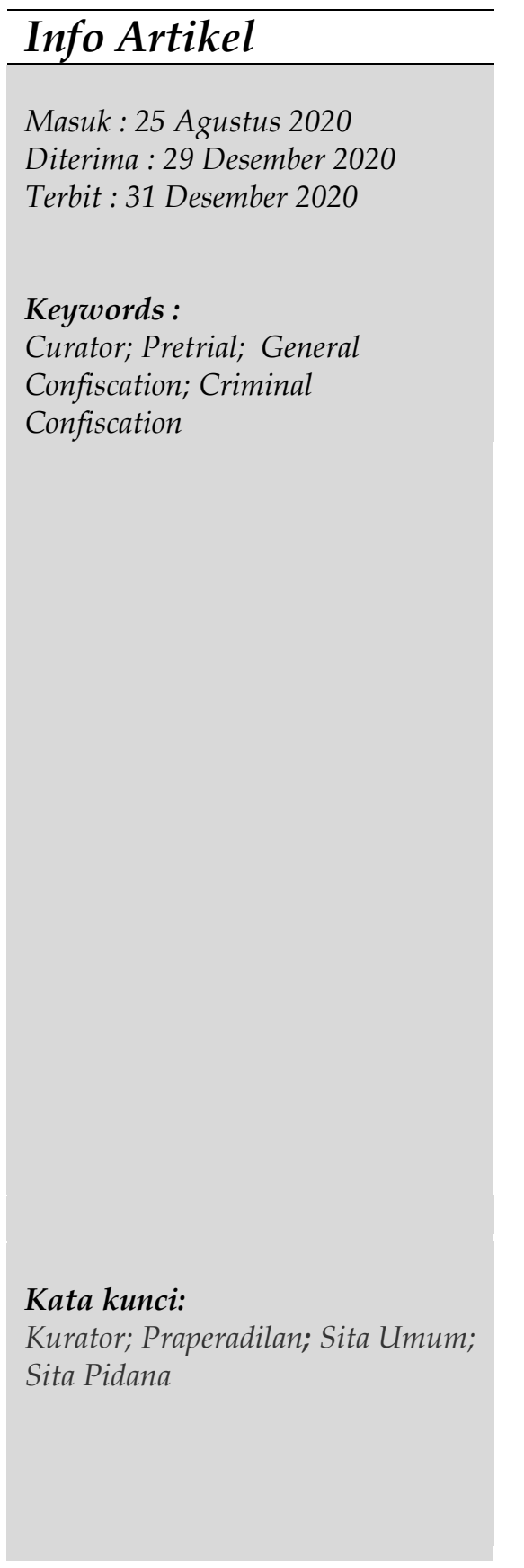

\begin{abstract}
The implication of a bankruptcy decision issued by the Commercial Court is that the debtor of bankruptcy assets can no longer gain access to his property The problem arises when, at the same time, the general confiscation of the bankruptcy of the debtor's assets has also been/will be subject to criminal confiscation. This article aims to discuss the curator's authority in managing confiscated assets under Law Number 37 of 2004 concerning Bankruptcy and Postponement of Debt Payment Obligations (Bankruptcy Law) and the right of the curator to file a pretrial in the case of bankrupt assets subjected to criminal confiscation based on legal certainty. The writing of this article reflects a normative juridical research with conceptual and statutory approaches to illustrate the concept discussed which is reviewed normatively based on the relevant laws and regulations. The results reveal that the curator in carrying out the settlement and/or management of the bankruptcy board can be held accountable for the condition that there is an error or negligence. As an implication, the curator can be held personally responsible on the grounds of being "detrimental" to the creditors' legal interest. In practice, curators are required to be reactive and responsive in taking action, while the Bankruptcy Law itself does not provide an opportunity to exercise discretionary power over on the condition of the bankruptcy assets which has been/will be placed the criminal confiscation. For the sake of realizing legal certainty, based on Article 82 paragraph (1) letter $b$ and Article 82 paragraph (3) Law Number 8 of 1981 concerning Criminal Procedure Law, curators can file pretrial lawsuit to review the legality of investigators or prosecutors actions that do not request supervisory judge's approval in conducting a confiscation to annul the status of the criminal confiscation on the bankruptcy assets.
\end{abstract}




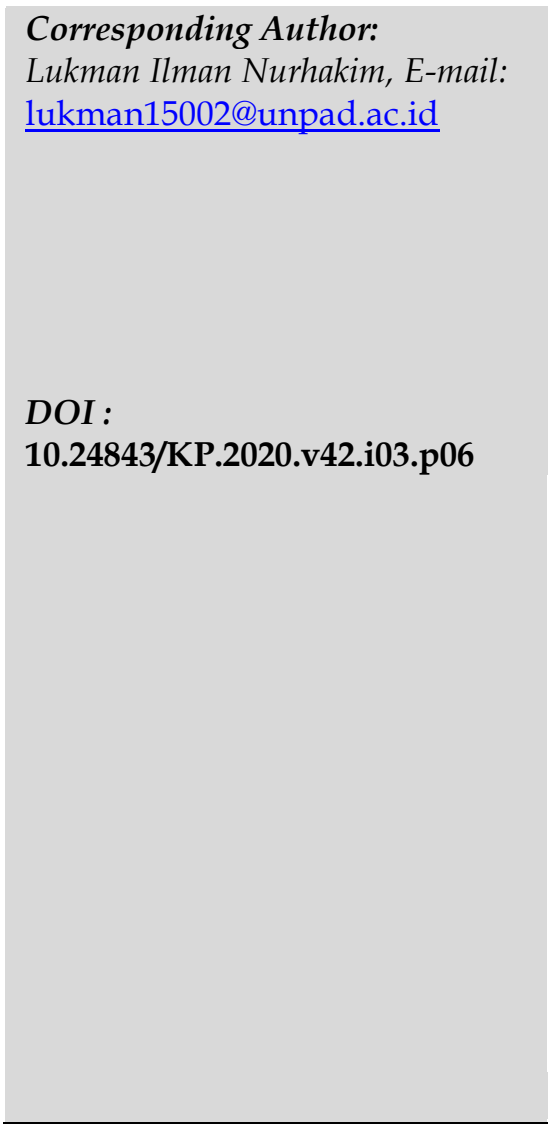

Kepailitan dan Penundaan Kewajiban Pembayaran Utang (UU Kepailitan) dan hak kurator untuk mengajukan praperadilan terhadap boedel kepailitan yang diletakkan sita pidana ditinjau dari kepastian hukum. Penulisan artikel ini bersifat penelitian yuridis normatif, dengan pendekatan konseptual dan peraturan perundang undangan agar dapat menggambarkan konsep yang dibahas yang dikaji secara normatif dengan mendasarkan pada peraturan perundang-undangan terkait. Hasil penelitian mengungkapkan bahwa kurator dalam pelaksanaan pemberesan dan/atau pengurusan boedel pailit dapat dimintakan pertanggungjawaban dengan syarat terdapat kesalahan atau kelalaian. Sebagai implikasinya, kurator dapat bertanggung jawab secara pribadi dengan alasan "merugikan" kepentingan hukum para kreditur. Dalam praktiknya, kurator dituntut reaktif dan responsif dalam mengambil tindakan, sedangkan UU Kepailitan sendiri tidak memberikan kesempatan untuk melakukan kewenangannya secara diskresif terhadap kondisi boedel pailit yang telah/akan diletakan sita pidana. Demi terwujudnya kepastian hukum, berdasarkan Pasal 82 ayat (1) hurufb dan Pasal 82 ayat (3) Undang-Undang Nomor 8 Tahun 1981 tentang Hukum Acara Pidana (KUHAP), maka kurator dapat mengajukan gugatan praperadilan untuk menguji untuk menguji keabsahan tindakan penyidik atau penuntut umum yang tidak meminta persetujuan hakim pengawas dalam melakukan suatu penyitaan demi membatalkan kedudukan sita pidana atas boedel pailit.

\section{Pendahuluan}

Debitor dikatakan pailit ketika tidak mampu melakukan pemenuhan kewajiban terhadap utang-utang atas namanya, dengan syarat minimal terdapat 2 (dua) utang yang telah jatuh tempo yang disebabkan oleh bermacam - macam, salah satunya sumber pendapatan Debitor sedang mengalami defisit. ${ }^{1}$ Kondisi demikian, menyaratkan kondisi Debitor tersebut memiliki dua Kreditor atau lebih dapat memenuhi ketentuan Pasal 2 ayat (1) Undang-Undang Nomor 37 Tahun 2004 tentang Kepailitan dan Penundaan Kewajiban Pembayaran Utang (untuk selanjutnya disebut UU Kepailitan) tentang persyaratan seseorang dapat dinyatakan pailit. ${ }^{2}$

Pengertian Pailit sendiri sebagaimana Pasal 1 angka 1 UU Kepailitan memberikan akibat hukum tidak hanya pada subjek debitor itu sendiri, melainkan juga sita umum terhadap harta kekayaan Debitor yang selanjutnya untuk pengurusuan dan pemberesannya secara hukum beralih pada Kurator, dengan atensi Hakim Pengawas. Sita umum sebagaimana dimaksud Pasal a quo merupakan peletakkan sita terhadap seluruh harta milik Debitor untuk kepentingan pelunasan seluruh utang Debitor (Boedel Pailit) yang

${ }^{1}$ Novitasari, (2017), Tinjauan Yuridis Pembatasan Jangka Waktu Penundaan Kewajiban Pembayaran Utang terhadap Debitor, Jurnal Kertha Patrrika Vol. 39 No. 2 Agustus 2017, DOI: https:doi.org/10.24843/KP.2017.v39.i02.p02, h. 101

2 Tanaya, P.E. dan Sudiarawan, K.A. (2017), Akibat Hukum Kepailitan Badan Usaha Milik Negara Pasca Berlakunya Undang - Undang Nomor 17 Tahun 2003 tentang Keuangan Negara, Jurnal Komunikasi Hukum, Volume 3, Nomor 1, Pebruari 2017, h. 117 - 126 DOI: http://dx.doi.org/10.23887/jkh.v3i1.9247, h. 120. 
dalam pengaturannya telah diatur tentang sita jaminan dalam Pasal 1131 dan Pasal 1132 Kitab Undang-Undang Hukum Perdata (untuk selanjutnya disebut KUHPerdata), dengan maksud untuk menghindari para Kreditor melakukan penyitaan atau eksekusi secara sendiri (eigenrichting). Para Kreditor (concursuscreditorum) terdiri dari 2 (dua) orang atau lebih secara hukum yang harus bertindak secara bersama-sama, utamanya dalam memperjuangkan hak setiap Kreditor terhadap seluruh harta Debitor secara berimbang (paritas creditorium). Oleh karena itu, Boedel Pailit harus dibagi secara adil dan proporsional kepada para Kreditor, kecuali terdapat alasan yang mengharuskan untuk didahulukan pembayarannya (pari passu prorate parte).

UU Kepailitan selain mengatur terkait pranata kepailitan, juga mengatur pranata penundaan kewajiban pembayaran utang (untuk selanjutnya disebut PKPU). Kedua pranata tersebut, baik dalam tataran teori maupun implementasinya, bertujuan untuk memberikan kepastian hukum, berupa perlindungan terhadap pihak - pihak yang memiliki hubungan hukum (Rechtsbetreeking), ketika kondisi Debitor dalam keadaan tidak mampu membayar dan/atau berhenti membayar. Dengan kata lain, lembaga kepailitan dan PKPU telah memberikan mekanisme perlindungan hukum yang jelas dengan menegasikan eksekusi secara sepihak oleh Kreditor dan menghentikan peluangpeluang Kreditor melakukan kecurangan atau yang dilakukan oleh Debitor itu sendiri, sehingga secara normatif segala perbuatan atau Tindakan melawan hukum dengan maksud untuk memperkaya diri sendiri maupun orang lain dapat terhindari ${ }^{3}$. Dengan demikian, konsekuensi hukum dari pernyataan pailit adalah Debitor Pailit tidak berwenang untuk mengoperasionalkan seluruh harta kekayaannya, baik diperoleh pada saat terbitnya Putusan yang menyatakan Debitor In Casu pailit maupun pada saat asset atau kekayaan In Casu didapatkan dari hasil pelaksanaan Putusan Pailit A quo, kemudian digunakan mekanisme sita jaminan atas harta kebendaan Debitor Pailit.

Kondisi-kondisi yang telah diuraikan di atas akan membawa kepada titik permasalahan terkait operasionalisasi pengaturan hukum ditinjau dari bingkai kepastian hukum, khususnya dalam pelaksanaan sita umum terhadap seluruh asset Debitor yang diperoleh sebelum,kepailitan begitupun segala akibat hukum atas terbitnya Putusan Pailit sebagaimana berdasarkan Pasal 31 ayat (2) UU Kepailitan. Pelaksanaan standard norm pada Pasal a quo dalam implementasi norma UU kepailitan dan KUHPerdata dengan telah dijatuhkan sita umum. Setelah itu, Kurator melakukan pemberesan terhadap Boedel Pailit dan Kreditor Separatis dapat melakukan eksekusi terhadap Harta Debitor yang telah dibebani jaminan atas kebendaan. Kondisi demikian berjalan ideal sampai kemudian menjadi tidak ideal ketika pada saat yang bersamaan sita umum kepalitan atas Asset Debitor dimaksud, juga telah/akan dibebani sita pidana.

Salah satu contoh kasus Penetapan Tersangka seorang Kurator dalam melaksanakan kewenangannya dalam melakukan pemberesan dan pengurusan harta Pailit Jo. Putusan Pengadilan Negeri Semarang Nomor: 12/Pid.Prap/2017/PN.Smg, dengan Pemohon selaku Kurator dalam perkara kepailitan Nomor: 9/Pdt.Sus-Pailit/2015/PN.Niaga.Smg yang dituduh melakukan tindak pidana Pencucian uang Jo. pemalsuan surat dalam kewenangannya melaksanakan perintah Hakim Pengawas. Majelis Hakim a quo

\footnotetext{
3 Budiono, Doni. (2018). Analisis Pengaturan Hukum Acara Kepailitan dan Penundaan Kewajiban Pembayaran Utang, Jurnal Hukum Acara Perdata Adhaper, Vol. 4 (2), 109-127, DOI: 10.36913/jhaper.v4i2.81, h. 112.
} 
menolak upaya Pemohon Praperadilan (Kurator) yang meminta agar dinyatakan tidak sah penetapan status Tersangka atas namanya. Dengan demikian, dalam praktik Kurator dalam melaksanakan kewenangannya tidak memiliki Hak Imunitas, sekalipun melaksanakan perintah undang - undang Jo. UU Kepailitan.

Sita Pidana dilihat dari pengaturannya diatur dalam Pasal 16 Undang - Undang Nomor 8 Tahun 1981 tentang Hukum Acara Pidana (untuk selanjutnya disebut KUHAP), diatur bahwa: baik benda bergerak maupun benda tida bergerak, berwujud maupun tidak berwujud dilakukan Tindakan untuk diambilalih dan disimpan di bawah Penyidik, utamanya demi kepentingan Pembuktian dalam agenda penyidikan, penuntutan, dan peradilan. Untuk memperjelas hal tersebut, M. Yahya Harahap telah memberikan pengertian penyitaan dalam ruang lingkup perdata agar selanjutnya dapat ditemukan sebagai pembeda, dengan mensyaratkan 4 :

a. Pemilik harta tidak dapat menguasai harta sepenuhnya atau dengan kata lain ditempatkan ke dalam mekanisme Sita Jaminan

b. Mekanisme sita jaminan dimaksud dilakukan oleh Organ Pengadilan atas perintah Hakim atau Putusan Pengadilan

c. Klasifikasi barang yang menjadi objek sita jaminan, selain dijadikan alasan untuk pelaksanaan putusan atas pelunasan hutang Debitor, yakni dengan proses pelelangan (Executorial Verkoop)

d. Pelaksanaan penyitaan tersebut dilaksanakan sejak dimintakan oleh Penggugat untuk selanjutnya dalam Putusan Sela Majelis Hakim mengindahkannya, hingga keluarnya Putusan Pengadilan yang Berkekuatan Hukum Tetap untuk menyatakan sah dan berharga sita jaminan tersebut.

Dalam konteks penyitaan, prinsip dasar hukum acara kepailitan adalah hukum acara perdata, kecuali ditentukan lain oleh UU Kepailitan. Dari Aspek Kepailitan, sita umum terhadap seluruh Asset Debitor yang kemudian pengaturannya merujuk kepada definisi kepailitan untuk melikuidasi Asset Debitor dengan tujuan agar Debitor tidak melakukan perbuatan melawan hukum terhadap kepentingan hukum (Rechtsbelaangen) para Krediturnya. Untuk itu, secara hukum Pasal 21 UU Kepailitan telah memberikan pengaturan jelas dan tegas terhadap segala sesuatu Asset Debitor Pailit yang diperoleh selama kepalitian, meliputi seluruh kekayaan Debitor pada saat putusan pernyataan pailit diucapkan.

Dari segi aspek Hukum Acara Pidana, sita Pidana ditujukan untuk kebutuhan pembuktian, salah satunya adalah bukti di persidangan. Konsekuensi terbesar dengan tidak dilakukannya sita pidana adalah dalil Penuntut Umum dalam surat dakwaan menjadi sulit untuk dibuktikan, maka demi menguraikan dalil dalam surat dakwaanya, Jaksa Penuntut Umum seringkali memperlihatkan benda - benda yang disinyalir sebagai alat bukti dalam persidangan, sehingga alat bukti yang sebelumnya telah dibebani sita pidana menjadi sangat penting dan sentral. Benda - benda yang disinyalir sebagai alat bukti dalam persidangan secara umum kita mengenalnya sebagai barang bukti (corpus delicti), yakni barang yang diperoleh sebagai hasil tindak pidana, maupun dalam pelaksanaan tindak pidana untuk selanjutnya menjadi barang bukti. Hal ini

\footnotetext{
${ }^{4}$ Harahap, M. Y. (2005). Hukum Acara Perdata tentang gugatan, persidangan, penyitaan, pembuktian, dan putusan pengadilan. Jakarta: Sinar Grafika. h. 282.
} 
sejalan dengan pendapat Andi Hamzah yang menguraikan pengertian barang bukti pada perkara pidana sebagai alat yang digunakan dalam menunaikan delik, juga hasil daripada delik. Pisau sebagai media untuk menikam korban (alat) dan Rumah Mewah sebagai hasil dari pidana Korupsi (hasil delik). ${ }^{5}$

Pada prakteknya, Kurator pada saat menjalankan tugasnya, beradu konflik kepentingan (Conflict of Interest) dengan Penyidik dan/atau Penuntut Umum, khususnya terkait peletakan sita kepailitan terhadap sita pidana atau sebaliknya. Kewenangan Kurator dalam metelakan sita Kepailitan sebagaimana adanya putusan Pailit, sedangkan kewenangan Penyidik dan Penuntut umum dalam meletakan Sita Pidana terhadap benda, yang secara definitive dibatasi oleh ketentuan Pasal 39 ayat (1) KUHAP, mengatur:

a. Diduga sebagai hasil daripada tindak pidana

b. Diduga sebagai alat dalam menunaikan atau mempersiapkan tindak pidana

c. Diduga sebagai alat untuk menghambat dilaksanakan penyidikan perkara pidana $a$ quo

d. Diduga secara khusus dibuat untuk menunaikan tindak pidana

e. Diduga memiliki hubungan langsung dengan tindak pidana yang dilakukan

Pasal 39 Ayat (1) KUHAP a quo mendasari Kurator tidak dapat menguasai harta pailit karena pada saat bersamaan Boedel Pailit juga merupakan barang bukti dalam perkara pidana untuk selanjutnya dibebani siita pidana demi kepentingan Penyidikan, Penuntutan, dan Mengadili Perkara Pidana Jo. Pasal 39 ayat (2) KUHAP. Namun, Pasal 46 KUHAP telah mensyaratkan terkait pengembalian benda yang telah diletakan sita pidana, sebagai berikut: sudah tidak diperlukan lagi bagi keperluan penyidikan dan penuntutan, perkara a quo bukan merupakan tindak pidana atau Tersangka tidak cukup bukti, Deponering atau perkara dikesampingkan demi kepentingan umum. Untuk itu, menindaklanjuti perkara yang sudah Inkracht, maka benda yang telah diletakan sita pidana dikembalikan lagi kepada siapa - siapa saja yang telah disebutkan dalam Putusan a quo, terkecuali Putusan a quo tidak mengatakan demikian atau untuk dimusnahkan.

Salah satu contoh kasus upaya kurator dalam mengajukan Gugatan Praperadilan, namun digugurkan melalui Putusan Pengadilan Negeri Banyuwangi Nomor: 2/Pid.Pra/2020/PN.Byw, dengan melibatkan: Pemohon. selaku Kurator berdasarkan Putusan Pengadilan Niaga dalam Pengadilan Negeri Surabaya Nomor: 7/Pdt.SusPKPU/2019 tertanggal 24 Mei 2019, sebagai Pemohon melawan Penuntut Umum dalam perkara pidana No: 665/Pid.B/2019/PN.Byw yang telah menjatuhkan sita pidana terhadap asset Boedel Pailit. Majelis Hakim yang memeriksa Perkara a quo dalam pertimbangan hukumnya menerangkan bahwa Pengadilan Negeri a quo memiliki kewenangan untuk memeriksa perkara Jo. Putusan Mahkamah Konstitusi Nomor: 102/PUU/VIII/2016. Majelis Hakim a quo menyatakan Permohonan Praperadilan a quo gugur, karena mendasari perkara pidana No: 665/Pid.B/2019/PN.Byw telah diputus beberapa hari sebelum diajukannya Gugatan Praperadilan a quo. Dengan demikian, hal ini menggambarkan bahwa sekalipun Putusan a quo tidak mempermasalahkan Legal Standing Kurator, hanya saja Putusan tersebut tidak memperhatikan kepentingan

${ }^{5}$ Hamzah, A. (1986), Kamus Hukum, Jakarta: Ghalia. h. 100. 
hukum (rechtsbelaang) untuk menghapus dan mengangkat sita pidana di atas Boedel Pailit Putusan Pengadilan Niaga dalam Pengadilan Negeri Surabaya Nomor: 7/Pdt.SusPKPU/2019.

UU Kepailitan telah memberikan perlindungan terhadap asset boedel pailit yang telah dikenakan sita pidana melalui Pasal 31 ayat (1) UU Kepailitan mengatur untuk segala peletakan sita terhadap boedel pailit menjadi tidak memiliki akibat hukum, dengan mekanisme Hakim Pengawas dapat melakukan pencoretan terhadapnya. Hanya saja, Penyidik atau Penuntut Umum seringkali mendalilkan Pasal 39 ayat (2) KUHAP sebagai dasar untuk meletakkan sita pidana. Ketidaksesuaian antara UU Kepailitan dengan KUHAP tersebut mengakibatkan tidak terpenuhinya Hak para Kreditor yang memiliki kepentingan hukum (Rechtsbelaang) terhadap boedel Pailit, sehingga tujuan daripada diletakan sita kepailitan untuk pemenuhan hak tiap kreditornya dapat terpenuhi secara proporsional.

Mencermati hal di atas, kesulitan Kurator dalam melaksanakan tugas - tugasnya sehingga memberikan tuntutan bahwa seorang Kurator harus memiliki profesional dan pemahaman komprehensif mengenai kepailitan. Kurator juga berkewajiban untuk menyampaikan laporan secara berkala kepada Hakim Pengawas. Perlu dimengerti bahwa pelakasanaan tugas kurator, selain membereskan Boedel Pailit juga bertugas untuk mengelola Boedel Pailit, dengan harapan nilainya dapat terus bertambah. Atas hal tersebut Kurator dituntut atas integritas berorientasi keadilan dan kebenaran, serta standar etika dan profesi agar dapat mengeliminasi konflik kepentingan antar Kreditor maupun Kreditur dengan Debitor. ${ }^{6}$ Kondisi demikian, hendaknya mewajibkan Kurator untuk melakukan upaya hukum atas perlindungan asset boedel pailit yang dikenakan juga sita pidana oleh Pidana. Dengan demiian, kewenangan Kurator dalam mengelola asset boedel pailit dan Hak Gugat Kurator terhadap asset boodel pailit yang dikenakan sita pidana perlu dianalisis lebih lanjut.

Berdasarkan hasil penelusuran Peneliti, terdapat beberapa tulisan Jurnal yang terkait dengan tema tulisan ini, di antaranya: Perlindungan Hukum Bagi Kreditor Hak Tanggungan dalam Eksekusi Harta (Boedel) Pailit terhadap Sita Pidana oleh Bernadetha Aurellia Oktavira dan Yudho Taruno Muryanyo ${ }^{7}$ memfokuskan penelitian kepada eksekusi kepentingan hukum pemegang Hak Tanggung sebagai kreditur preference, Sita Umum Kepailitan Mendahului dalam Pemberesan Harta Pailit oleh Siti Hapsah Isfardiyana ${ }^{8}$ memfokuskan kepada sita pidana yang diletakan di atas asset boedel Pailit yang sebelumnya telah dibebani hak istimewa, dan Penyitaan Benda dalam Kepailitan oleh Kurator dan Penyitaan Benda oleh Kepolisian dalam Perkara Pidana oleh Oktaviani

6 Akrisman, (2015), Pelaksanaan Tugas Kurator dalam Mengurus Harta Pailit Berdasarkan Pasal 72 Undang - Undang No. 37 Tahun 2004 tentang Kepailitan dan Penundaan Kewajiban Pembayaran Utang, Jurnal Pro Hukum, Vol. IV, No. 1, Juni 2015, http://journal.unigres.ac.id/index.php//urnalProHukum/article/view/504, h. 11

7 Oktavira, B. A., \& Muryanto, Y. T. (2020) Perlindungan Hukum Bagi Kreditor Pemegang Hak Tanggungan Dalam Eksekusi Harta (Boedel) Pailit Terhadap Sita Perkara Pidana. Jurnal Privat Law, 8(1), 63-69.

8 Isfardiyana, S. H. (2016). Sita Umum Kepailitan Mendahului Sita Pidana dalam Pemberesan Harta Pailit. Padjadjaran Journal of Law,3(3), 628-650., DOI: https://doi.org/10.22304/pjih.v3n3.a10 
F. Tambunan ${ }^{9}$ memfokuskan kepada kewenangan kepolisian dalam melakukan sita umum, sekalipun terhadap barang tersebut telah dibebani sita kepailitan. Ketiga jurnal tersebut bertitik pokok kepada titik singgung ketika Sita Pailit dan Sita Pidana bertemu, baik sita pailit terlebih dahulu kemudian diletakan Sita Pidana, maupun sebaliknya. Penulisan artikel ini bertitik tolak kepada kewenangan kurator baik dilihat dari tugas, fungsi, dan tanggung jawabnya dihubungkan dengan operasionalisasi asset Boedel pailit, selanjutnya Legal Standing Kurator dalam mengajukan Praperadilan terhadap Asset Bodel Pailit yang telah atau baru diletakan sita pidana di atasnya sebagai bentuk konkritisasi kewenangan Kurator demi mengutamakan kepentingan hukum para Kreditur. Dengan demikian, artikel ini membahas kewenangan Kurator dalam mengelola dan membereskan asset boedel Pailit dan Hak Gugat Kurator dalam terhadap asset boedel pailit yang dikenakan sita pidana mendasari kepastian hukum.

\section{Metode Penelitian}

Metode penelitian dalam penulisan artikel ini adalah yuridis normatif yang berbasis kepada data sekunder, berupa bahan hukum primer, sekunder, dan tersier terkait pengaturan eksisting terkait dengan tugas dan kewenangan kurator dalam mengelola dan membereskan Boedel Pailit, khususnya yang diletakannya juga sita pidana di atasnya. ${ }^{10}$ Bahan hukum primer yang digunakan dalam penulisan artikel ini adalah KUHAP, UU Kepailitan, dan putusan pengadilan terkait, sedangkan bahan hukum sekunder adalah buku dan tulisan jurnal terkait dengan materi kewenangan kurator dalam pengurusan asset boedel pailit dan hak kurator dalam mengajukan gugatan Praperadilan atas peletakan sita pidana terhadap asset boedel pailit, serta bahan hukum tersier yang digunakan dalam artikel ini adalah kamus hukum. Penelitian artikel ini menggunakan pendekatan perundang - undangan, dan pendekatan konseptual karena membahas suatu bentuk konsep penyelesaian sengketa terhadap asset boedel paili yang telah/akan dibebani sita pidana, serta teknik pengumpulan data dalam penulisan artikel ini menggunakan penelitian kepustakaan, dengan meramu dan mereformulasi pendapat, teori, dan/atau pengaturan terkait pokok permasalahan.

\section{Hasil Dan Pembahasan}

\subsection{Praktek Kurator dalam mengurus dan membereskan Boedel Pailit berdasarkan UU Kepailitan}

UU Kepailitan memberikan pedoman kepada Balai Harta Peninggalan atau Perseorangan agar dapat melakukan pengurusan dan pemberesa terhadap Boedel Pailit, dengan arahan Hakim Pengawas untuk selanjutnya disebut sebagai Kurator dan terhadapnya diberikan persyaratan, khususnya untuk perseorangan agar memiliki kompetensi khusus sesuai bidangnya untuk melakukan pengurusan dan pemberesan Boedel Pailit, sehingga untuknya harus didaftarkan kepada Kementerian Hukum dan Hak Asasi ManusiaJo. Pasal 70 UU Kepailitan.

9 Tambunan, O. F. (2019). Penyitaan Benda dalam Kepailitan oleh Kurator dan Penyitaan Benda oleh Kepolisian dalam Perkara Pidana, Verstek Jurnal Hukum Acara, Vol. 7 (2), 167-173.

10 Marzuki, Peter Mahmud. (2011). Penelitian Hukum, Jakarta: Kencana Prenada Media Group, h. 35 . 
Kewajiban Kurator untuk mengurus dan membereskan Boedel Pailit sebagaimana menjadi tugas utamanya, menurut Jerry Hoff menyinggung tentang tujuan kepailitan, yakni untuk melindungi kepentingan Kreditor dalam memperoleh haknya dengan memperhatikan klasifikasi dan proporsonalitas tuntutan hak mereka. Berkaitan dengan hal tersebut, Kurator sebagai suatu profesi mulia harus dapat bertindak atau mengambil keputusan setepat mungkin utamanya memperhatikan hak para Kreditor. Kurator juga dalam menjalankan tugasnya bertindak untuk dan atas nama Debitor, dengan demikian seyogyanya menjaga hak Debitor yang tersisa. Dengan kata lain, baik kepentingan para Kreditor maupun kepentingan Debitor keduanya harus mendapatkan perlakuan yang proporsional dari Kurator dalam melaksanakan tugasnya.

Kurator mulai melaksanakan segala kewenangan dan tugas yang melekat padanya terhitung sejak terbitnya Putusan Pailit. Kemudian UU Kepailitan telah memberikan batasan - batasan terhadap hal tersebut dengan tujuan agar jelas batas gradasi antara Kurator dalam melakukan wewenang dan tugasnya secara inherent atau mandiri, dan mendapatkan sepengetahuan dan/atau sepersetujuan dari Hakim Pengawas. Hal tersebut dapat dimengerti karena fungsi dan peran Kurator yang sangat strategis, sehingga untuk menghindari hal - hal yang menyalahi kewajibannya oleh -undangundang telah diatur terkait proporsi yang jelas untuk dapat meminimalisir Kurator mendapati gugatan dari para Kreditor, pihak ketiga, bahkan Debitor sendiri.

Pertama, pelaksanaan pemberesan boedel Pailit oleh Kurator pada padanannya memiliki implikasi yuridis. UU Kepailitan menghendaki bahwa pelaksanaan pemberesan dimaksud salah satunya melakukan penawaran penjualan dengan harga pantas, agar hasil pendapatan dari penjualan barang In Casu dapat memenuhi hak para Kreditor Konkuren secara adil dan berimbang. Ada hal yang perlu diperhatikan dengan seksama, bahwa terhadap penawaran penjualan Boedel Pailit melalui lelang dilakukan tanpa adanya persetujuan dari Hakim Pengawas, namun beda halnya dengan penjualan lansung atau di bawah tangan karena Kurator dapat melakukan hal tersebut apabila sebelumnya telah mendapatkan persetujuan dari Hakim Pengawas. Dengan adanya sepersetujuan dari Hakim Pengawas menghindari perbuatan Kurator terhadap perbuatan, baik untuk memperkaya diri sendiri maupun orang lain.

Implikasi adanya Putusan Pailit yang dikeluarkan oleh Pengadilan Niaga adalah Debitor sebagai pemilik Boedel Pailit tidak bisa mengoperasionalkan serta mengakses hartanya. Dengan kata lain, demi hukum Gugatan yang diajukan oleh salah satu Kreditor terhadap pemenuhan prestasi atau kewajiban atasnya gugur sebagaimana diatur dalam Pasal 21, Pasal 24 ayat (1), serta Pasal 29 UU Kepailitan, sehingga satu satunya upaya yang dapat ditempuh Kreditor adalah mengajukan peletakan sita jaminan mengacu pada Jo. Pasal 10 UU Kepailitan.

UU Kepailitan mengatur peran Hakim Pengawas dalam mengawasi tugas kurator melakukan pemberesan dan pengurusan Boedel Pailit sebagaimana diatur dalam Pasal 65 UU Kepailitan demi mencegah hal - hal yang berkaitan dengan mengutamakan baik secara pribadi maupun bersama - sama untuk kepentingan Debitor, Kreditor, maupun Kurator, sehingga UU Kepailitan mengatur bahwa Hakim Pengawas berkewajiban untuk meminimalisir dan/atau mengeliminasi tindakan-tindakan Kurator terhadap boedel Pailit untuk menguntungkan diri pribadi maupun orang lain sesuai dengan tugas dan kewenangannya dalam membereskan dan mengurus Boedel Pailit. 
Kesalahan atau kelalaian Kurator dalam pelaksanaaan pemberesan dan/atau pengurusan Boedel Pailit dapat dimintai pertanggungjawabannya. Untuk itu Kurator berdasarkan Pasal 74 ayat (1) UU Kepailitan setiap 3 (tiga) bulan sekali wajib melaporkan kinerjanya kepada Hakim Pengawas, dan demi memenuhi asas publisitas hasil laporan tersebut dapat diakses oleh setiap orang, termasuk para Kreditor sebagaimana dikehendaki Pasal 74 ayat (2) UU Kepailitan.

Berikut adalah tabulasi terkait Kewenangan dan Tugas Kurator ketika melakukan Pemberesan harta pailit ${ }^{11}$ :

\begin{tabular}{|c|l|l|}
\hline No. & \multicolumn{1}{|c|}{ Wewenang dan Tugas } & Pengaturan Pasal \\
\hline 1. & $\begin{array}{l}\text { Kurator mulai melakukan } \\
\text { pemberesan Boedel Pailit, setelah } \\
\text { adanya Putusan Pailit }\end{array}$ & Pasal 175 UU Kepailitan \\
\hline 2. & $\begin{array}{l}\text { Pemberesan dimaksud adalah } \\
\text { melakukan penjualan, baik melalui } \\
\text { lelang maupun di bawah tangan } \\
\text { tanpa sepersetujuan Debitor }\end{array}$ & Pasal 184 ayat (1) UU Kepailitan \\
\hline 3. & $\begin{array}{l}\text { Mengambil keputusan terhadap } \\
\text { benda yang tidak dapat atau kunjung } \\
\text { dilakukan pemberesan }\end{array}$ & Pasal 184 ayat (3) UU Kepailitan \\
\hline 4. & $\begin{array}{l}\text { Mengikutsertakan Debitor Pailit } \\
\text { dalam hal pelaksanaan tugasnya, } \\
\text { dengan catatan Debitor berhak atas } \\
\text { upah }\end{array}$ & Pasal 186 UU Kepailitan \\
\hline
\end{tabular}

Selain melakukan Pemberesan Boedel Pailit, Kurator juga dalam prakteknya melakukan pembagian Boedel Pailit dengan sepengetahuan dan/atau sepersetujuan Hakim Pengawas dengan mekanisme sebagaimana diatur dalam Pasal 189 UU, Pasal 192 ayat (1), (2), (3), dan (5), serta Pasal 201 UU Kepailitan, sebagai berikut:

a. Pencocokan terhadap daftar pembagian, dengan rincian:

1) Pendapatan dan Pengeluaran;

2) Daftar Kreditor; dan

3) Jumlah Piutang

b. Membuat daftar pembagian untuk selanjutnya didaftarkan pada Kepaniteraan Pengadilan Niaga

c. Pengumuman terhadap surat - surat pembagian di surat kabar terkait mengingat tenggang waktu yang ada;

d. Apabila ada pihak yang berkeberatan terhadap daftar pembagian tersebut, Hakim Pengawas berkewajiban untuk membuat penetapan untuk selanjutnya diberitahukan kepada Kurator;

11 Undang - Undang Nomor 37 Tahun 2004 tentang Kepailitan dan Penundaan Kewajiban Pembayaran Utang 
e. Memberitahukan dalam sidang terbuka terkait alasan penetapan daftar pembagian yang telah diumumkan;

f. Mengingat waktu untuk pengumuman di surat - surat telah berakhir dan sudah terbit Putusan terhadap perlawanan atasnya, maka Kurator wajib melaksanakan pembagian sebagaimana telah dicantumkan dalam Putusan

Tanggung jawab Kurator dalam melaksanakan kewenangan dan tugasnya terhadap Boedel Pailit sebagaimana dijelaskan di atas dapat dimintai pertanggungjawaban, apabila atas tindakan dan/atau keputusannya tersebut mengakibatkan adanya kerugian terhadap Boedel Pailit sebagaimana diatur dalam Pasal 72 UU Kepailitan. Selanjutnya, apabila dalam pengurusannya Kurator tidak mendapatkan izin Hakim Pengawas atau kuasa, padahal undang - undang menentukan demikian Jo. Pasal 83 UU Kepailitan dan Pasal 84 UU Kepailitan, maka akibat dari Tindakan dan/atau keputusannya tersebut tetap sah secara hukum, namun pertanggungjawaban pribadi dikenakan atas tindakan dan/atau keputusannya tersebut sebagaimana diatur dalam Pasal 78 ayat (2) UU Kepailitan.

Atas ketentuan di atas, gugatan dapat saja dilayangkan kepada Kurator atas dasar kelalaian atau kesalahan dalam bertindak dan/atau mengambil keputusan, karena UU Kepailitan seyogyanya telah mengatur secara rigid perihal hal tersebut. Untuk itu, Legal Standing bagi pihak - pihak yang merasa dirugikan atas peristiwa tersebut dapat dianggap sah secara hukum, khususnya Kreditor Konkuren. Adapun alasan gugatan sebagaimana dimaksud adalah Perbuatan Melawan Hukum yang dilakukan oleh Kurator dalam melaksanakan tugasnya menyebabkan berkurangnya nilai Boedel Pailit, sehingga para Kreditor tidak mendapatkan hak sebagaimana mestinya dikarenakan kelalaian atau kesalahan Kurator tersebut di atas. ${ }^{12}$

Kurator secara hukum diwajibkan untuk memperjuangkan kepentingan para Kreditor atas pengurusan dan pemberesan Boedel pailit, tapi tak ayal hal tersebut bisa menjadi boomerang, sehingga kurator dapat dimintai pertanggungjawabannya ketika ada kesalahan atau kelalaian yang dapat merugikan kepentingan hukum para Kreditor. Di satu sisi lain, Kurator oleh UU Kepailitan diberikan kekuasan bebas, selain memiliki tanggung jawab yang sangat besar juga yang dalam arti sempit Kurator dapat bertindak secara mandiri atau tidak membutuhkan pengetahuan atau persetujuan Hakim Pengawas Jis. Pasal 16 ayat (1) , Pasal 69 ayat (2) , dan Pasal 184 ayat (1) UU Kepailitan, juga dalam melakukan tindakannya Kurator tetap harus mendapatkan pengetahuan atau persetujuan Hakm Pengawas yang oleh UU Kepailitan ditujukan untuk menghindari adanya itikad tidak baik dari Kurator dalam melaksanakan kewenangandan tugasnya.

Kurator dapat menanggung pertanggungjawaban secara pribadi dengan alasan "merugikan" kepentingan hukum atas Boedel Pailit memperhatikan ketentuanketentuan dalam UU Kepailitan. Hal ini seyogyanya perlu mendapatkan perhatian lebih lanjut karena dalam praktek Kurator dituntut reaktif dan responsif dalam mengambil Tindakan, sedangkan UU Kepailitan sendiri tidak "keleluasaan" terhadap kondisi demikian. Dengan demikian, meninjau dari kebutuhan praktik dan norma yang ada,

12 Sjahdeini, Sutan Remy. (2010). Hukum Kepailitan Memahami UU No. 3 Tahun 2004 Tentang Kepailitan, Jakarta: Pustaka Utama Grafiti, h. 226. 
maka UU Kepailitan dituntut selain untuk memberikan perlindungan hukum bagi para pihak yang berkepentingan terhadap Boedel Pailit, juga seyogyanya perlu memberikan "hak imunitas" bagi Kurator dalam melaksanakan tugasnya dalam melakukan pemberesan dan pembagian Boedel Pailit In casu.

Berdasarkan hal di atas, dapat dipahami bahwa kedudukan Kurator sebagai pihak yang memiliki tugas, fungsi, dan tanggung jawab secara hukum memiliki peranan yang sangat besar, sehingga keberadaannya seharusnya didukung oleh struktur pembinaan atau pengawasan, khususnya oleh organisasi yang menaungi Kurator saat ini, di antaranya: Asosiasi Kurator dan Pengurus Indonesia (AKPI), Himpunan Kurator dan Pengurus Indonesia (HKPI), dan Ikatan Kurator dan Pengurus Indonesia (IKAPI) yang masing - masing memiliki kode etik ${ }^{13}$, sehingga sistem pengawasan melalui pendekatan organisasi tidak terintegrasi. Hal tersebut, disebabkan oleh permasalahan norma yang ada di dalam UU Kepailitan, khususnya terkait profesi Kurator oleh BPHN dirangkum sebagai berikut ${ }^{14}$ :

a. Ketidakjelasan pengangkatan (sumpah/pelantikan) Kurator sebagai profesi dan/atau Kurator Pengurus harta pailit Jis.. Pasal 15 dan Pasal 70 UU Kepailitan;

b. Tidak adanya pengawasan terhadap profesi Kurator, dikaitkan tidak adanya pengaturan UU Kepailitan terhadapnya atau diserahkan kepada organisasi masing - masing melalui perangkat etik;

c. Seiring besarnya peranan dan tanggung jawab Kurator, tidak didukung dengan pengaturan UU kepailitan terhadap kewajiban Kurator dalam memberikan informasi kepada Hakim Pengawas, Kreditor dan Debitor. Namun, semenjak adanya Surat Edaran Mahkamah Agung Nomor 2 Tahun 2016 tentang Penanganan Perkara Kepailitan dan Penundaan Kewajiban Pembayaran Utang di Pengadilan, pada pokoknya Hakim Pengawas dapat meminta informasi terhadap Kurator terkait tugas dan kewenangannya terhadap asset boedel pailit.

Dengan demikian, diperlukan adanya pembaharuan terhadap UU Kepailitan, khususnya terkait penengasan pengawasan Kurator dalam melakukan tugas dan tanggung jawabnya, serta adanya ketentuan terkait hak imunitas dan diskresi Kurator dalam melaksanakan tugasnya, dengan catatan selama masih sesuai dengan kewenangannya.

\subsection{Hak Gugat Kurator terhadap Asset Boedel Pailit yang Dikenakan Sita Pidana berdasarkan Kepastian Hukum}

Kurator berdasarkan Pasal 1 angka 5 UU Kepailitan diklasifikasikan, yakni: Perseorangan atau Badan Harta Peninggalan (BPH) dalam membereskan dan mengurus Boedel Pailit diangkat berdasarkan Putusan Pailit serta diawasi oleh Hakim Pengawas. Konsekuensi terhadap diangkatnya Kurator adalah, para Kreditor tidak dikehendaki

13 Raden Besse Kartoningrat, (2016) Fungsi Etik Profesi bagi Kurator dalam Menjalankan Tugas, Jurnal Perspektif, Vol. XXI No. 2, DOI: http://dx.doi.org/10.30742/perspektif.v21i2.18 h. 115

14 Kementerian Hukum dan Hak Asasi Manusia Badan Pembinaan Hukum Nasional, (2018), “Naskah Akademik Rancangan Undang - Undang tentang Perubahan atas Undang - Undang Republik Indonesia Nomor 37 Tahun 2004 tentang Kepailitan dan Penundaan Kewajiban Pembayaran Utang", https://www.bphn.go.id/data/documents/naskah_akademik_ruu_ kepailitan_dan_pkpu_final_2018.pdf. h. 97-116. 
untuk mengajukan peletakan sita terhadap Boedel Pailit Debitor atau mengajukan eksekusi secara terpisah atau parsial, melainkan Kurator dapat mewakili kepentingan Para Kreditor keseluruhan untuk meletakan sita secara bersama - sama. Dengan demikian, kedudukan Debitor yang dinyatakan Pailit secara hukum tidak dapat bertindak sebagai pihak yang bersengketa dan untuk itu Kurator atas wewenang dan fungsinya mewakili segala urusan Debitor, baik dalam melakukan pengurusan maupun pemberesan hartanya atau Boedel Pailit.

Ketentuan di atas tidak berlaku mutlak karena nyatanya UU Kepailitan masih membuka ruang bagi pihak - pihak yang berkepentingan untuk menyelesaiakan permasalahannya secara parsial di Pengadilan Negeri, karena ketentuan UU Kepailitan bersifat materiil dalam arti pemberlakukan sita Kepailitan sebagaimana dimaksud ditujukan untuk melindungi kepentingan hukum (Rechtsbelaang) para Kreditor. UU Kepailitan pada padanannya tidak dapat mengubah pengaturan formil yang ada, karena mengajukan gugatan di muka persidangan adalah hak konstitusinal semua warga negara berdasarkan Pasal 27 ayat (1) Undang-Undang Dasar Negara Republik Indonesia Tahun 1945 (untuk selanjutnya disebut UUD NRI Tahun 1945).

Kurator dalam melaksanakan wewenang dan tugasnya, tidak dilengkapi dengan "Hak Imunitas" yang dalam Pasal 72 UU Kepailitan dapat dikenakan pertanggungjawaban atas kelalaian atau kesalahannya di dalam menggunakan kewenangan dan menjalankan tugasnya, sehingga menimbulkan kerugian terhadap Boedel Pailit. Keberadaan Kurator dalam UU Kepailitan pada padanannya menegasikan ketentuan terkait pelaksanaan Sita Umum sebagaimana diatur dalam Pasal 1131 dan Pasal 1132 KUHPerdata, sehingga Debitor selaku pemillik Boedel Pailit terhindar dari perilaku memperkaya diri sendiri dan/atau orang lain utamanya terkait pemenuhan hak para Kreditor (tidak proporsional).

Akibat-akibat hukum selain yang dijelaskan di atas, berimplikasi pada hilangnya hubungan hukum (Rechtsbetreeking) antara Debitor dengan Asset Boedel Pailit, untuk selanjutnya digantikan oleh Kurator melalui Putusan Pengadilan Niaga. Selanjutnya, segala perbuatan hukum terhadap operasionalisasi Asset Debitor Pailit oleh Kurator oleh UU Kepailitan diwajibkan untuk dipublikasikan pada Surat Kabar, demi terpenuhinya asas publisitas. Perlu menjadi catatan, bahwa tidak semua Asset Debitor menjadi Boedel Pailit, karena nyatnya Pasal 22 UU Kepailitan tetap memperhatikan kepentingan Debitor dalam mengoperasionalisasi hartanya secara limitatif, semata - mata hanya untuk pemenuhan kebutuhan hidup dan/atau nafkah keluarga bukan merupakan bagian dari kewenangan Kurator. Juga, Asset Debitor Pailit yang telah dibebani jaminan kebendaan, salah satunya adalah Hak Tanggungan secara hukum tetap memiliki kekuatan executorial atau dapat dimintakan fiat eksekusi memperhatikan ketentuan Pasal 6 Undang - Undang Nomor 4 Tahun 1996 tentang Hak Tanggungan atas Tanah. Oleh karena itu, Kurator juga tidak berwenang dalam mengoperasionalisasikan harta yang telah dijaminkan untuk selanjutnya dapat dieksekusi oleh Kreditor Separatis atau seolah - olah tidak terjadi kepailitan.

Pengadilan Niaga melalui Putusan Pailitnya mendelegasikan seorang Hakim Pengawas untuk mengawal prosesi kepailitan terhadap tugas Kurator dalam membereskan dan mengurus Boedel Pailit Jo. Pasal 65 dan Pasal 69 ayat (5) UU Kepailitan, mengatur bahwa Kurator secara atributif berhak untuk mengajukan gugatan terhadap pihak ketiga yang 
dapat merugikan Boedel Pailit, sebagaimana telah memperoleh izin dari Hakim Pengawas. Terbatasnya kewenangan Kurator dalam "memperjuangkan" nilai Boedel Pailit oleh UU Kepailitan hanya diberikan kewenangan secara mandiri dalam mengajukan tuntutan hukum kepada pihak ketiga sebatas terhadap pencocokan piutang, perlakuan terhadap hutang yang belum jatuh tempo, sewa menyewa yang belum jatuh tempo, setelah lewat waktu masa insolvensi.

Salah satu tujuan hukum, yakni Kepastian Hukum menurut Gustav Radbuch meyakini sebagai pencipta norma - norma yang memberikan jaminan atas berfungsinya peraturan tersebut dalam tataran operasionalisasinya. ${ }^{15}$ Berkaitan dengan hal tersebut, Hukum dituntut untuk memberikan perlindungan hukum terhadap peristiwa peristiwa hukum yang selanjutnya memiliki akibat hukum. Untuk itu hukum dalam arti kelembagaan hukum atau instutusinya dibatasi oleh hukum terkait potensi adanya kesewenang - wenangan (wileukeur). Selanjutnya, Renner menambahkan dalam hal kepastian bagi peristiwa-peristiwa konkrit dengan cenderung memilih lembaga hukum sebagai dasar penelitiannya, mengenai seberapa jauh tatanan hukum sesuai dengan fungsi sosial dari suatu lembaga, ${ }^{16}$ Oleh karena itu, Pasal 24 UUD NRI Tahun 1945 mengatur terkait kewenangan Mahkamah Agung sebagai Lembaga Kekuasaan Kehakiman dituntut untuk mewujudkan salah satu tujuan hukum, yakni kepastian hukum

Kurator dalam melakukan upaya hukum atas asset Boedel Pailit yang dikenakan sita pidana hendaknya memperhatikan kewenangan mengadili pengadilan, dengan memperhatikan lingkup kewenangan Praperadilan dan Pengadilan Niaga, untuk menjawab persoalan ini, maka Kurator perlu mencermati ketentuan Pasal 82 ayat (3) huruf d KUHAP dan Buku II angka 22 Pedoman Mahkamah Agung, mengatur: Hakim yang menangani perkara Praperadilan dapat memeriksa terkait keabsahan penetapan barang bukti, untuk selanjutnya diiadili dan diputusan terhadapnya. Pengaturan dan Penjelasan Pasal 3 ayat (1) UU Kepailitan memberikan akomodasi terhadap pihak pihak yang merasa dirugikan atas dilakukannya sita pidana terhadap boedel Pailit.

Pengaturan penyitaan yang tersebar di berbagai perundang - undangan, sehingga menyebabkan disharmonis dapat mengakibatkan adanya tumpang tindih antar sektor, sebagai contoh dalam penulisan artikel ini sita pidana berdomain pada KUHAP dan sita kepailitan berdomain pada UU Kepailitan. ${ }^{17}$ Kurator dapat mengajukan Gugatan Praperadilan mengacu pada ketentuan Pasal 82 ayat (3) huruf d KUHAP yang pada pokoknya dinyatakan bahwa Kurator harus dapat membuktikan bahwa Barang Sitaan sebagai objek gugatan, atas adanya Putusan Pailit senyatanya harus dikembalikan kepada pemilik barang tersebut menjadi Boedel Pailit. Legal Standing Kurator dalam mengajukan Gugatan Praperadilan juga didasari dengan adanya Putusan Pailit, sehingga secara hukum Kurator dapat mewakili untuk dan/atas nama Debitor untuk

15 L. Tanya Bernard, (2010), Teori Hukum Strategi Tertib Manusia Lintas Ruang dan Generasi Yogyakarta Genta Publishing, h. 106.

16 Friedman W. (1994). Teori dan Filsafat Hukum dan Masalah - Masalah Kontemporer, Jakarta: Raja Grafindo, h. 2-3.

17 Nola, Luthvi Febryka. (2018). Kedudukan Sita Umum terhadap Sita Lainnya dalam Proses Kepailitan (The Position Of General Seizure Towards Others In The Process Of Bankrupcy), Jurnal Negara Hukum: Membangun Hukum untuk Keadilan dan Kesejahteraan, Vol. 9 (2), 217 - 234 DOI: 10.22212/jnh.v9i2.1047, h. 229. 
menuntut adanya "potensi" kerugian karena diletakannya sita pidana di atas sita Boedel Pailit sebagaimana diatur dalam Pasal 95 ayat (1) KUHAP, untuk selanjutnya meminta agar Hakim menyatakan agar peletakan sita jaminan tersebut tidak sah. Dengan demikian, secara hukum Kurator dalam mengajukan Gugatan Praperadilan mewakili kepentingan Kreditor terhadap pemberesan Boedel Pailit atas peletakan sita pidana atas Boedel Pailit adalah tidak sah. KUHAP memberikan kewenangan bagi Kurator untuk mengajukan tuntutan ganti rugi apabila ada penurunan nilai asset Boedel Pailit sebagai akibat dari adanya peletakkan sita pidana.

Tidak sahnya penetapan sita pidana di atas asset boedel pailit oleh Pasal 31 ayat (1) UU Kepailitan secara hukum dihentikan seketika atas segala penetapan yang ditujukan, termasuk sita pidana yang dibebankan di atas boedel pailit. Ketentuan tersebut berlaku terhadap penetapan sita pidana yang telah diletakan, lalu terhadap peletakan sita pidana setelah diucapkannya Putusan Pailit, seharusnya Penyidik atau Penuntut Umum meminta izin terhadap Hakim Pengawas, apabila tidak maka Kurator dapat mengajukan mekanisme Praperadilan. ${ }^{18}$ Dalil Legal Standing dan hak gugat kurator tersebut apabila ditinjau dari segi teori hukum, salah satunya adalah kepastian hukum agar segala peristiwa dan hubungan hukum yang terjadi secara hukum tidak menimbulkan tumpang tindih, ketidakjelasan, atau kesumiran. Selain itu, salah satu tujuan hukum lainnya, yakni tercapainya keadilan juga harus tetap diperhatikan, sama seperti penulisan artikel ini kepastian dalam prosesi perkara pidana seringkali menanggalkan rasa keadilan para Kreditor "harapan" adanya pemenuhan hak dari asset boedel pailit yang telah diletakan sita pidana. Namun, KUHAP sendiri telah mengatur terkait pedoman hakim dalam mengadili perkara Praperadilan berdasarkan Pasal 82 ayat (1) huruf b KUHAP yang secara tersurat mengharuskan Hakim untuk mendengarkan dari kedua belah pihak atau implementasi atas asas audi et alternam partem. Dengan demikian, berdasarkan apa yang ditentukan oleh pasal-pasal tersebut dapat dipahami bahwa Pengadilan Negeri berwenang untuk menangani keberatan terhadap penyitaan, sebagaimana pasal 82 ayat (1) huruf B KUHAP, mengatur sah atau tidaknya peletakan sita Pidana terhadap barang yang berkaitan dengan tindak pidana, juga menjadi implikasi hasil Putusan Pailit yang selanjutnya ditetapkan sebagai boedel Pailit.

Praperadilan secara etimologis dipahami sebagai pemeriksaaan pendahuluan sebelum pemeriksaan terhadap pokok perkara (dakwaan). ${ }^{19}$ Tujuan praperadilan sendiri adalah untuk memberikan perlindungan hak asasi manusia terhadap apabila ada cacat prosedur maupun subtansi terhadap setiap tingkat pemeriksaan dalam hal penyelidikan, penyidikan, dan penuntutan sebagaimana salah satunya adalah penyitaan terhadap barang yang memiliki hubungan dengan tindak pidana In Casu. Penyidik dalam praktek seringkali meletakan sita pidana di atasnya dengan alasan harta yang menjadi boedel pailit tersebut diduga diperoleh secara melawan hukum, baik merupakan hasil tindak pidana pencucian uang atau tindak pidana korupsi. ${ }^{20}$ Atas dasar ini, Pengadilan Negeri wajib memperhatikan syarat sah penyitaan untuk selanjutnya dapat diperiksa agar selanjutnya dapat ditetapkan bahwa apakah peletakan sita pidana terhadap barang bersangkutan dapat dinyatakan sah atau tidaknya melalui mekanisme Praperadilan.

18 Oktavira, B. A., \& Muryanto, Y. T., Op.Cit., h. 67-68

19 Hamzah, A. Op.Cit., h. 187.

20 Isfardiyana, S. H., Op.Cit., h. 630-631 
Hal ini sejalan dengan tujuan KUHAP menghendaki agar lembaga Praperadilan ini dapat dapat dilakukan pengawasan horizontal di dalam sistem peradilan pidana, yang selanjutnya dapat memberikan kepastian dalam lingkup hukum pidana dan keadilan bagi para pihak yang memilki kepentingan hukum (Rechtsbelaangen) terhadap barang yang diletakan sita pidana

Kurator berdasarkan kewenangan dan tugasnya dalam membereskan dan mengelola Asset Boedel Pailit dapat mengajukan gugatan praperadilan terhadap pembatalan terhadap barang yang diletakan sita pidana. Selanjutnya, hakim pengadilan negeri yang menangani kasus gugatan praperadilan diharuskan dapat melihat objek sengketa secara komprehensif atau setidak - tidaknya dapat memastikan bahwa objek tersebut telah memenuhi persyaratan diletakan sita pidana untuk kepentingan pembuktian dalam penyidikan, penuntutan, dan peradilan. ${ }^{21}$ Apabila di dalam persidangan Penyidik tidak dapat membuktikan atas alasan dilakukannya sita pidana di atas boedel pailit tersebut, maka Hakim dapat memerintahkan Penyidik untuk mengembalikan objek sengketa kepada Kurator untuk selanjutnya dilakukan pengurusan dan pemberesan terhadap boedel pailit tersebut.22 Maka, Kurator dapat mendalilkan bahwa tindakan Penyidik yang tidak meminta persetujuan Hakim Pengawas dalam meletakkan sita pidana di atas boedel pailit, dinilai tidak memenuhi ketentuan peraturan perundang-undangan sehubungan telah adanya hubungan hukum (Rechtsbetreeking) antara benda tersebut dengan pranata kepailitan yang diatur dalam UU Kepailitan.

\section{Kesimpulan}

UU Kepailitan mengatur peran Hakim Pengawas dalam mengawasi tugas kurator melakukan pemberesan dan pengurusan Boedel Pailit. Permasalahan hukum muncul ketika terjadi kesalahan atau kelalaian Kurator dalam pelaksanaaan pemberesan dan/atau pengurusan boedel Pailit, sehingga Kurator dapat dimintai pertanggungjawabannya oleh Kreditor. Hanya saja, UU Kepailitan dinilai belum cukup mengakomodasi peran dan fungsi kurator dalam melaksanakan tugasnya sebagaimana UU Kepailitan di satu sisi menuntut Kurator agar reaktif dan responsif dalam mengambil Tindakan yang berkontradiksi dengan tidak diberikannya kewenangan bebas (diskresi) dan hak imunitas pada Kurator dalam UU Kepailitan.

Kurator dalam mengajukan Gugatan Praperadilan mewakili kepentingan Kreditor terhadap pemberesan boedel pailit berdasarkan UU Kepailitan atas peletakan sita pidana atas Boedel Pailit adalah tidak sah, namun KUHAP memberikan kewenangan bagi Kurator untuk mengajukan tuntutan ganti rugi apabila ada penurunan nilai asset boedel Pailit sebagai akibat dari adanya peletakkan sita pidana. Demi terwujudnya kepastian hukum, berdasarkan Pasal 82 ayat (1) huruf b KUHAP dan Pasal 82 ayat (3) KUHAP, maka Kurator dapat mengajukan guugatan Praperadilan, sehingga Hakim Praperadilan dapat mempertimbangkan tindakan Penyidik atau Penuntut Umum yang tidak meminta persetujuan Hakim Pengawas untuk menentukan sah atau tidaknya suatu penyitaan demi membatalkan kedudukan sita pidana atas boedel pailit

21 Fernando, J., \& Nugroho, S. A. (2018). Kedudukan Sita Pidana Terhadap Sita Umum Kepailitan. Jurnal Hukum Adigama, Vol. 1 (1), h. 339-363., DOI: http://dx.doi.org/10.24912/ adigama.v1i1.2148, h. 12

22 Tambunan, O. F., Op.Cit., h. 173. 


\section{Ucapan terima Kasih (Acknowledgments)}

Penulis Ucapkan terima kasih kepada pihak - pihak yang telah berkontribusi dalam penelitian ini, khususnya Program Academic Grant Leadership (ALG) yang telah mendanai penelitian ini, termasuk anggota penelitian lainnya seperti: Dr. Elis Rusmiati, S.H.,M.H., Dr. H. Artaji, S.H.,M.H., Dr. Anita Afriana, S.H.,M.H., Hazar Kusmayanti, S.H.,M.H., dan Sherly Ayuna Putri, S.H., MH. yang membantu hingga artikel ini dapat terbit

\section{Daftar Pustaka / Daftar Referensi}

\section{$\underline{\text { Buku }}$}

Agung, Mahkamah, (2010), Himpunan Hasil Rapat Kerja Nasional Mahkamah Agung Republik Indonesia dengan Jajaran Pengadilan pada 4 (empat) Lingkungan Peradilan di Seluruh Indonesa Tahun 2007 dan Tahun 2008, Perpustakaan dan Layanan Informasi Biro hukum dan Humas Badan Urusan Administrasi, Mahkamah Agung Republik Indonesia

Friedman, W, (1994), Teori dan Filsafat Hukum dan Masalah - Masalah Kontemporer, Jakarta: Rajagrafindo Persada

Hamzah, A. (1986), Kamus Hukum, Jakarta: Ghalia.

Harahap, M. Y. (2005). Hukum Acara Perdata tentang gugatan, persidangan, penyitaan, pembuktian, dan putusan pengadilan. Jakarta: Sinar Grafika.

L. Bernard, Tanya, (2010), Teori Hukum Strategi Tertib manusia Lintas Ruang dan Generasi, Yogyakarta: Genta Publishing

Marzuki, Peter Mahmud. (2011). Penelitian Hukum, Jakarta: Kencana Prenada Media Group.

Sjahdeini, Sutan Remy. (2010). Hukum Kepailitan Memahami UU No. 37 Tahun 2004 Tentang Kepailitan, Jakarta: Pustaka Utama Grafiti.

\section{Jurnal}

Akrisman, Pelaksanaan Tugas Kurator dalam Mengurus Harta Pailit Berdasarkan Pasal 72 Undang - Undang No. 37 Tahun 2004 tentang Kepailitan dan Penundaan Kewajiban Pembayaran Utang, Jurnal Pro Hukum, Vol. IV, No. 1, Juni 2015. http://journal.unigres.ac.id/index.php//urnalProHukum/article/view/504.

Besse Raden Kartoningrat, (2016) Fungsi Etik Profesi bagi Kurator dalam Menjalankan Tugas, Jurnal Perspektif, Vol. XXI No. 2, DOI: http://dx.doi.org/10.30742/perspektif.v21i2.18.

Budiono, Doni. (2018). Analisis Pengaturan Hukum Acara Kepailitan dan Penundaan Kewajiban Pembayaran Utang, Jurnal Hukum Acara Perdata Adhaper, Vol. 4 (2), 109-127, DOI: 10.36913/jhaper.v4i2.81.

Tanaya, P.E. dan Sudiarawan, K.A. (2017), Akibat Hukum Kepailitan Badan Usaha Milik Negara Pasca Berlakunya Undang - Undang Nomor 17 Tahun 2003 tentang 
Keuangan Negara, Jurnal Komunikasi Hukum, Volume 3, Nomor 1, Pebruari 2017, h. 117 - 126 DOI: http:/ / dx.doi.org/10.23887/jkh.v3i1.9247,

Fernando, J., \& Nugroho, S. A. (2018). Kedudukan Sita Pidana Terhadap Sita Umum Kepailitan. Jurnal Hukum Adigama, Vol. 1 (1), h. 339-363., DOI: http://dx.doi.org/10.24912/ adigama.v1i1.2148.

Isfardiyana, S. H. (2016). Sita Umum Kepailitan Mendahului Sita Pidana dalam Pemberesan Harta Pailit. Padjadjaran Journal of Law,3(3), 628-650., DOI: https://doi.org/10.22304/piih.v3n3.a10.

Nola, Luthvi Febryka. (2018). Kedudukan Sita Umum terhadap Sita Lainnya dalam Proses Kepailitan (The Position Of General Seizure Towards Others In The Process Of Bankrupcy), Jurnal Negara Hukum: Membangun Hukum untuk Keadilan dan Kesejahteraan, Vol. 9 (2), 217 - 234, h. 229., DOI: 10.22212/jnh.v9i2.1047

Novitasari, (2017), Tinjauan Yuridis Pembatasan Jangka Waktu Penundaan Kewajiban Pembayaran Utang terhadap Debitor, Jurnal Kertha Patrrika Vol. 39 No. 2 Agustus 2017, DOI: https://doi.org/10.24843/KP.2017.v39.i02.p02.

Oktavira, B. A., \& Muryanto, Y. T. (2020). Perlindungan Hukum Bagi Kreditor Pemegang Hak Tanggungan Dalam Eksekusi Harta (Boedel) Pailit Terhadap Sita Perkara Pidana. Jurnal Privat Law, 8(1), 63-69.

Tambunan, O. F. (2019). Penyitaan Benda dalam Kepailitan oleh Kurator dan Penyitaan Benda oleh Kepolisian dalam Perkara Pidana, Verstek Jurnal Hukum Acara, Vol. 7 (2), 167-173.

\section{Tesis atau Disertasi}

Suriadiredja Shalahuddin, (2011), Kewenangan Kurator dalam Pengurusan dan Pemberesan Harta Debitor Pailit Berdasarkan Undang - Undang epailtan dan PKPU No. 37 Tahun 2004 (Studi kasus PT Kayamatex vs PT SK Keris Perkara Nomor: 013 K/N/2006), Universitas Indonesia

Dharmawan Doni, (2016), Judicial Review terhadap Kewenangan Kurator dalam Mengurus dan Membereskan Harta Pailit, Universitas Islam Indonesia

\section{Website Resmi}

Kementerian Hukum dan Hak Asasi Manusia Badan Pembinaan Hukum Nasional, (2018), "Naskah Akademik Rancangan Undang - Undang tentang Perubahan atas Undang - Undang Republik Indonesia Nomor 37 Tahun 2004 tentang Kepailitan dan Penundaan Kewajiban Pembayaran Utang", https://www.bphn.go.id/data/documents/naskah_akademik_ruu_kepailitan _dan_pkpu_final_2018.pdf.

\section{Peraturan Perundang - Undangan}

Undang-Undang Dasar Negara Republik Indonesia Tahun 1945

Kitab Undang-Undang Hukum Perdata (KUHPerdata

Undang - Undang Nomor 4 Tahun 1996 tentang Hak Tanggungan atas Tanah 
Undang-Undang Nomor 8 Tahun 1981 tentang Hukum Acara Pidana (Kitab UndangUndang Hukum Pidana)

Undang-Undang Nomor 37 Tahun 2004 tentang Kepailitan dan Penundaan Kewajiban Pembayaran Utang (UU Kepailitan)

Putusan Pengadilan Negeri Semarang Nomor: 12/Pid.Prap/2017/PN.Smg,

Putusan Pengadilan Niaga dalam Pengadilan Negeri Semarang Nomor: 9/Pdt.SusPailit/2015/PN.Niaga.Smg

Putusan Pengadilan Negeri Banyuwangi Nomor: 2/Pid.Pra/2020/PN.Byw

Putusan Pengadilan Niaga dalam Pengadilan Negeri Surabaya Nomor: 7/Pdt.SusPKPU/2019

Putusan Mahkamah Konstitusi Nomor: 102/PUU/VIII/2016

Surat Edaran Mahkamah Agung Nomor 2 Tahun 2016 tentang Penanganan Perkara Kepailitan dan Penundaan Kewajiban Pembayaran Utang di Pengadilan 